\title{
LOW-MOLECULAR-WEIGHT RHEUMATOID FACTOR *
}

\author{
BY W. B. CHODIRKER $\dagger$ AND T. B. TOMASI, JR. \\ (From the Division of Experimental Medicine, University of Vermont College of Medicine, \\ Burlington, $V t$.)
}

(Submitted for publication December 31, 1962; accepted February 21, 1963)

The interaction of rheumatoid sera with gamma globulin has been known for many years. This reaction, detectable by a variety of serological tests (sensitized sheep cell agglutination, latex fixation, FII precipitin, etc.), has been found, in recent years, to be mediated by a macroglobulin commonly called the rheumatoid factor (2). Similar if not identical macroglobulins have been detected in the sera obtained from patients with a variety of chronic granulomatous and inflammatory diseases (tuberculosis, sarcoidosis, kalaazar, syphilis, etc.) (3-5). Although considerable clinical and experimental work has been done in this area, the significance of these factors remains uncertain. Widely held at the present time is the concept that the rheumatoid factor represents an antibody specific for gamma globulin in an altered form (6). In support of this concept are $a$ ) the striking physicochemical and immunological similarities between the rheumatoid factor and certain well-established macroglobulin antibodies (typhoid-O agglutinins, antipneumococcal antibody, isoagglutinins, etc.) $(7) ; b$ ) the plasma cell origin of the rheumatoid factors $(8)$; and $c$ ) the marked specificity shown by the closely related anti-Gm factors for the genetically determined gamma globulins (9). Very little is known, however, of the antigenic stimulus and the immunizing events, deficiencies which have retarded acceptance of the rheumatoid factor as an antibody in the classic sense.

Recently, complexes of gamma globulin with sedimentation coefficients between 7 and $19 \mathrm{~S}$ have

* A preliminary report of this work was presented at the ninth interim scientific session of the American Rheumatism Association, Richmond, Va., December 7, 1962, and appeared in abstract form (1). This work was supported by grant AM-03986-03S1, from the National Institutes of Health, Bethesda, Md., and by grant G19 381, the National Science Foundation.

$\dagger$ Fellow, Canadian Arthritis and Rheumatism Society.

¥ Senior Investigator, Arthritis and Rheumatism Foundation. been found in the sera of patients with rheumatoid arthritis (10), Sjögren's syndrome, and idiopathic pulmonary fibrosis (11). Kunkel, MüllerEberhard, Fudenberg, and Tomasi (10) found these complexes in the euglobulin fraction of the serum and showed that they were dissociated to $7 \mathrm{~S}$ subunits by acid buffers and 4 to $6 \mathrm{M}$ urea, but not by sulfhydryl reagents. Since many of the properties of these complexes were similar to those of the $22 \mathrm{~S}$ complexes frequently seen in rheumatoid sera, it was suggested that the intermediate complexes represented the in vivo interaction of gamma globulin with $7 \mathrm{~S}$ rheumatoid factor.

The existence of a low-molecular-weight rheumatoid factor analogous to the $7 \mathrm{~S}$ counterparts of the classical macroglobulin antibodies would constitute further presumptive evidence for the antibody nature of the rheumatoid factor.

The results of this investigation indicate the existence of two varieties of rheumatoid factor in some rheumatoid sera having intermediate complexes. One is the sulfhydryl-sensitive $19 \mathrm{~S}$ rheumatoid factor, the other a low-molecular-weight factor that is stable in the presence of sulfhydryl reagents.

\section{MATERIALS AND METHODS}

Twelve serum samples obtained from eight patients were studied. The sera, obtained from several sources, ${ }^{1}$ are listed in Table I. All had high titers of rheumatoid factor in the latex fixation test. Six of the sera were obtained from patients with rheumatoid arthritis, three with intermediate complexes (Em, Do, and $\mathrm{Sn})$, and three with no complexes ( $\mathrm{Db}, \mathrm{Dn}$, and $\mathrm{Bc}$ ). Three of the rheumatoid sera were obtained from cases complicated by Felty's syndrome (Em), Sjögren's syndrome $(\mathrm{Sn})$, and pulmonary fibrosis $(\mathrm{Bc})$. None of the rheu-

\footnotetext{
1 Sera were kindly provided by Dr. C. A. Rosenberg, Veterans Administration Hospital, Batavia, N. Y.; Dr. J. H. Bland, Department of Medicine, University of Vermont College of Medicine; and Drs. J. Vaughan and V. Butler, Department of Medicine, University of Rochester School of Medicine and Dentistry.
} 
TABLE I

Summary of clinical and laboratory data of patients studied

\begin{tabular}{|c|c|c|c|c|c|c|c|}
\hline Patient & Age & Diagnosis & $\begin{array}{l}\text { Serum } \\
\text { date }\end{array}$ & $\begin{array}{l}\text { Int. } \\
\text { comp. }\end{array}$ & $\begin{array}{r}\text { Total } \\
\text { protein }\end{array}$ & $\underset{\text { globulin }}{\text { Gamma }}$ & $\begin{array}{c}\text { Latex fixation } \\
\text { titer (reciprocal) }\end{array}$ \\
\hline Em & $\begin{array}{c}\text { years } \\
61\end{array}$ & $\begin{array}{l}\text { Rheumatoid arthritis } \\
\text { Leukopenia } \\
\text { Hepatomegaly } \\
\text { Splenomegaly }\end{array}$ & $\begin{array}{l}\text { July '61 } \\
\text { Aug. '61 } \\
\text { Jan. '62 } \\
\text { June '62 }\end{array}$ & $\begin{array}{c}0 \text { to } 4+ \\
4 \\
3 \\
1 \\
3\end{array}$ & $\begin{array}{c}\mathrm{g} / 100 \mathrm{ml} \\
8.1 \\
6.8 \\
6.1 \\
7.3\end{array}$ & $\begin{array}{c}\mathrm{g} / 100 \mathrm{ml} \\
3.57 \\
2.90 \\
1.56 \\
3.12\end{array}$ & $\begin{array}{r}81,920 \\
20,480 \\
1,280 \\
20,480\end{array}$ \\
\hline Do & 28 & Rheumatoid arthritis & & 3 & 7.6 & 2.45 & 640,000 \\
\hline $\mathrm{Sn}$ & 58 & $\begin{array}{l}\text { Rheumatoid arthritis } \\
\text { Sjögren's syndrome }\end{array}$ & $\begin{array}{l}\text { Aug. '61 } \\
\text { Oct. '61 }\end{array}$ & $\begin{array}{l}2 \\
1\end{array}$ & $\begin{array}{l}5.8 \\
7.5\end{array}$ & $\begin{array}{l}1.63 \\
1.79\end{array}$ & $\begin{array}{r}1,300,000 \\
20,480\end{array}$ \\
\hline $\mathrm{Db}$ & 35 & Rheumatoid arthritis & & 0 & 7.3 & 1.32 & 20,480 \\
\hline Dn & 56 & Rheumatoid arthritis & & 0 & 6.8 & 1.51 & 10.240 \\
\hline $\mathrm{Bc}$ & 71 & $\begin{array}{l}\text { Rheumatoid arthritis } \\
\text { Pulmonary fibrosis }\end{array}$ & & 0 & 7.5 & 3.0 & 20,480 \\
\hline$Y d$ & 65 & Hepatic cirrhosis & & 0 & 9.4 & 5.26 & 10,240 \\
\hline $\mathrm{Be}$ & 59 & $\begin{array}{l}\text { Waldenström's } \\
\text { macroglobulinemia }\end{array}$ & & $\mathbf{0}$ & 7.4 & 3.63 & $10,240^{*}$ \\
\hline
\end{tabular}

* Rheumatoid factor activity determined by latex fixation test performed at $\mathrm{pH}$ 7.0.

matoid sera demonstrated a cryoglobulin precipitate, or contained complement-fixing antibodies to human lung, liver, or kidney antigens, or to calf thymus nuclei.

Also included in this study were serum Yd from a patient with hepatic cirrhosis and serum Be, previously studied by Kritzman, Kunkel, McCarthy, and Mellors (12), from a patient with Waldenström's macroglobulinemia. Both were hypergammaglobulinemic with high latex fixation titers and cryoglobulin precipitates.

Analytical ultracentrifugation was performed with the Spinco model $\mathrm{E}$ ultracentrifuge as described previously (2). Centrifugation was at $52,640 \mathrm{rpm}$ and $20.0^{\circ} \mathrm{C}$. A 1 to $4+$ scale was used to semiquantitate the amounts of intermediate complexes present.

Total serum proteins were determined from measurements of refractive indexes with the temperature-com-
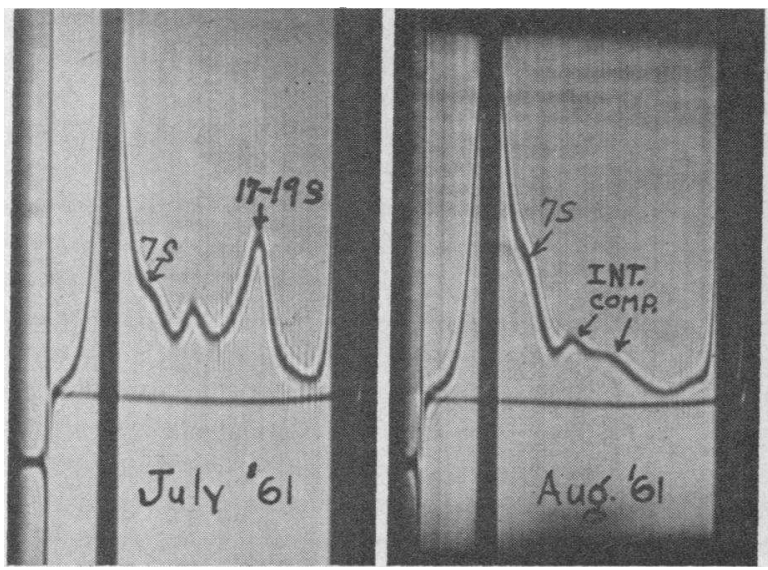

Fig. 1. Ultracentrifugal patterns of four Serum SAmples obtained from Em during one year. Centrifuga-
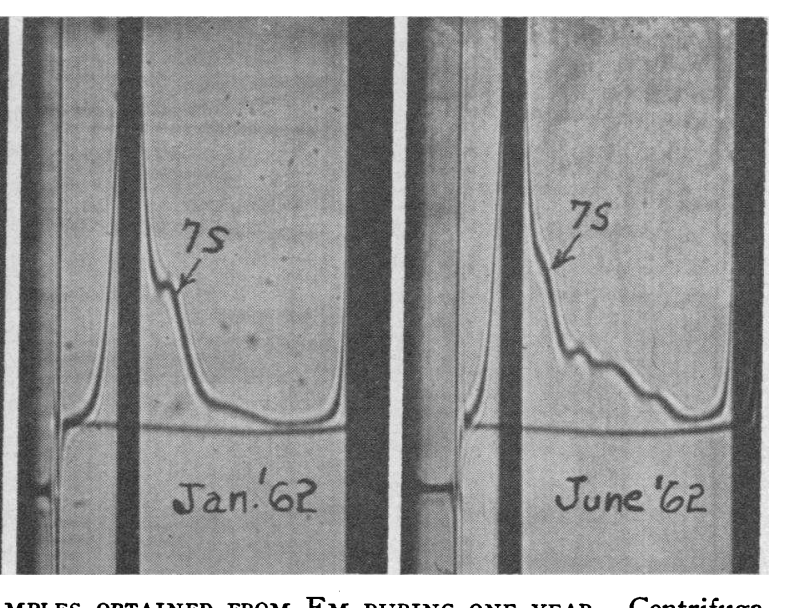
tion proceeds from left to right.

pensated American Optical T.S. meter. Protein determinations were carried out according to the modified Folin-Ciocalteu method (13). Gamma globulin was quantitated from the total serum protein concentration and the percentage of gamma globulin on the paper electrophoretograms of whole serum.

Density gradient ultracentrifugation was carried out as described by Kunkel (14) in a Spinco model L ultracentrifuge with a swinging bucket rotor and a gradient of 10 to $40 \%$ sucrose. Centrifugation was allowed to proceed at $35,000 \mathrm{rpm}$ for 16 to 18 hours. The gradient was collected in a series of 25 to 30 tubes through a small needle puncture in the bottom of the tube. The tubes pooled into 4 to 8 fractions were dialyzed exhaustively against phosphate buffer of $\mathrm{pH} 7.3$, ionic strength 0.15 . 


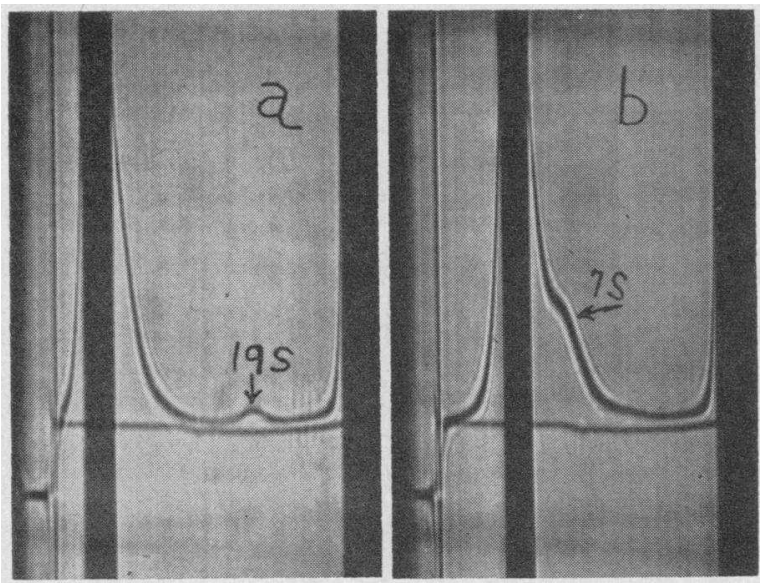

Fig. 2. Ultracentrifugal PATtern OF SERUM Db at (a) 48 MINUTES AND (b) 80 MinUtes OF CENTRIFUGATION. Centrifugation proceeds from left to right.

Column chromatography was carried out as described by Fahey (15). One $\mathrm{ml}$ of whole serum dialyzed against the initial buffer was applied to columns $(0.90 \mathrm{~cm}$ i.d.) containing $3 \mathrm{~g}$ of DEAE cellulose ${ }^{2}$ packed under 5-pound pressure to a height of $31 \mathrm{~cm}$. In two instances (columns $\mathrm{Do}$ and $\mathrm{Be}$ ), 75 and $25 \mathrm{mg}$, respectively, of a euglobulin preparation were chromatographed. A continuous gradient of decreasing $\mathrm{pH}$ and increasing ionic strength with an initial $0.03 \mathrm{M}$ phosphate buffer of $\mathrm{pH}$ 7.3, and a final $0.4 \mathrm{M}$ buffer of $\mathrm{pH} 4.8$ was employed.

Disulfide bonds were reduced by allowing samples of serum, made $0.1 \mathrm{M}$ with respect to 2-mercaptoethanol, to stand at room temperature in tightly stoppered tubes for 24 hours. After prolonged dialysis against $0.02 \mathrm{M}$ iodo-

2 DEAE cellulose was purchased from Brown Inc., Berlin, N. H. acetamide in $0.85 \%$ saline, rheumatoid factor activity was determined. Control sera were treated as above except that $0.85 \%$ saline was added instead of 2 -mercaptoethanol.

The latex fixation test of Singer and Plotz (16) was used to determine rheumatoid factor activity in the density gradient and chromatographic fractions and in the disulfide reduction experiments.

Double diffusion in $1 \%$ agar gel was performed as described previously (17) with rabbit antisera to localize the albumin and $7 \mathrm{~S}$ and $19 \mathrm{~S}$ gamma globulins in the density gradient and chromatographic experiments.

\section{RESULTS}

Analytical ultracentrifugation. A considerable variation in ultracentrifuge patterns, protein concentrations, and latex fixation titers of the four serum samples obtained from Em over a period of one year is seen in Figure 1 and Table I. A broad distribution of proteins with sedimentation constants greater than 7 are noted in the serum of July, 1961. The sharp peak of 17 to $19 \mathrm{~S}$ in this sample was not present in any of the other samples studied. After a prostatectomy complicated by an $E$. coli septicemia, the serum of January, 1962, showed a marked diminution of intermediate complexes coincident with a near-normal gamma globulin $(1.56 \mathrm{~g}$ per $100 \mathrm{ml})$ and a much lower latex fixation titer $(1 / 1,280)$. The sera of August, 1961, and June, 1962, had very similar ultracentrifuge patterns, protein concentrations, and rheumatoid factor activities. Serum Sn also showed considerable variability in the amount of
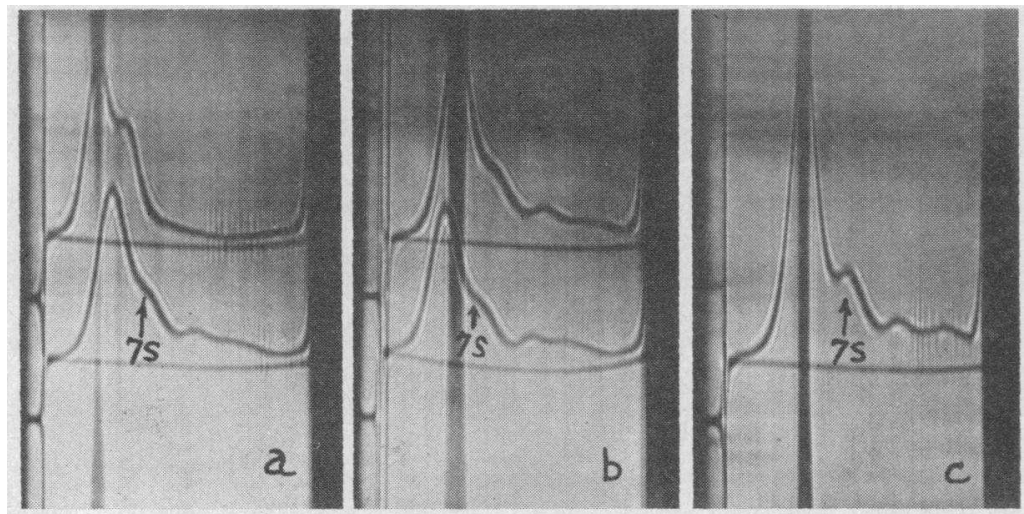

Fig. 3. EFFECT OF ACID AND 2-Mercaptoethanol ON THE UltracentriFUGE PATTERN OF SERUM EM. a) Untreated (bottom), after dialysis against glycine-saline buffer of $\mathrm{pH} 3.0$ (top). b) Untreated (top), after dialysis of acidified serum against phosphate buffer of $\mathrm{pH} 7.3$ (bottom). c) Serum made $0.1 \mathrm{M}$ with respect to 2 -mercaptoethanol. Centrifugation proceeds from left to right. 


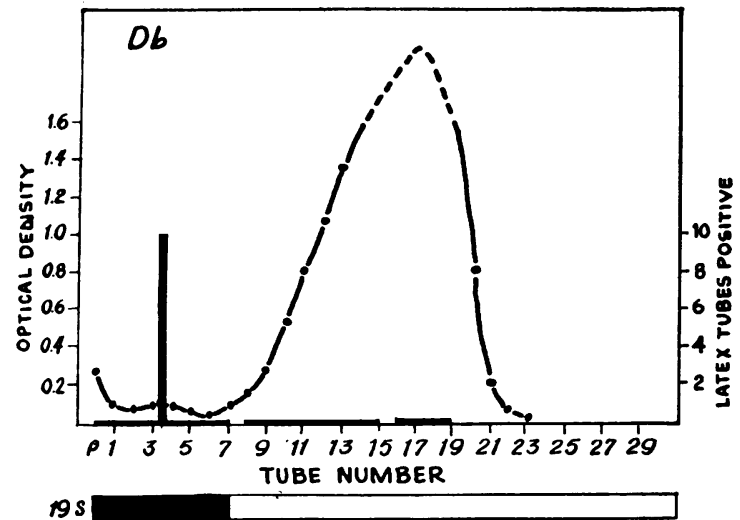

Fig. 4. Density gradient pattern of Serum Db. Horizontal bars at base line indicate the pooled tubes. Vertical bars indicate tubes positive in latex fixation test. Location of immunologically detected $19 \mathrm{~S}$ gamma globulin indicated below.

intermediate complexes and rheumatoid factor activity in different serum samples. The ultracentrifuge pattern of serum $\mathrm{Db}$, seen in Figure 2, contained no intermediate complexes. Sera Dn and $\mathrm{Bc}$ were similar to $\mathrm{Db}$ except that $\mathrm{Bc}$ had a $22 \mathrm{~S}$ complex. Serum Yd showed an elevation of $7 \mathrm{~S}$ proteins, but no intermediate complexes. Serum Be showed a high concentration of a homogeneous protein representing the abnormal macroglobulin $(18.5 \mathrm{~S})$. No intermediate complexes were present.

Effect of acid, alkali, and 2-mercaptoethanol. The effect of acid and 2-mercaptoethanol on the protein pattern of serum $\mathrm{Em}$ is seen in Figure 3. After dialysis against $0.1 \mathrm{M}$ glycine-saline buffer

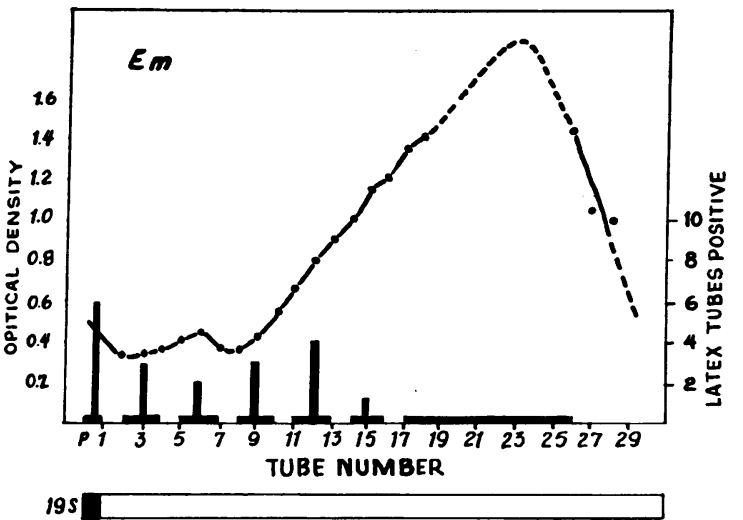

Fig. 5. Density gradient pattern of Serum Em. Horizontal bars at base line indicate the pooled tubes. Vertical bars indicate tubes positive in latex fixation test. Location of immunologically detected $19 \mathrm{~S}$ gamma globulin indicated below.

of $\mathrm{pH} 3.0$, a marked decrease in the amount of intermediate complexes and a corresponding increase in $7 \mathrm{~S}$ gamma globulin was noted (Figure 3a). Dialysis of the acidified serum against phosphate buffer of $\mathrm{pH} 7.3$ resulted in the reformation of the complexes (Figure $3 \mathrm{~b}$ ); these were unchanged at $\mathrm{pH} 9.6$, but completely dissociated at $\mathrm{pH}$ 10.6. No apparent change in pattern or amount of intermediate complexes was noted in serum made $0.1 \mathrm{M}$ with respect to 2 -mercaptoethanol (Figure 3c).

Density gradient ultracentrifugation. The distribution of rheumatoid factor activity in all experiments fell into one of two groups exemplified by the sera $\mathrm{Db}$ (Figure 4) and Em (Figure 5).

TABLE II

Results of density gradient, chromatographic, and sulfhydryl experiments

\begin{tabular}{|c|c|c|c|c|c|c|c|c|c|c|c|}
\hline \multirow[b]{4}{*}{ Serum } & \multirow{4}{*}{$\begin{array}{l}\text { Intermediate } \\
\text { complexes }\end{array}$} & \multicolumn{10}{|c|}{ Latex fixation tubes positive } \\
\hline & & \multirow{2}{*}{\multicolumn{4}{|c|}{ Density gradient }} & \multicolumn{4}{|c|}{ Chromatography } & \multicolumn{2}{|c|}{ Disulfide reduction } \\
\hline & & & & & & \multirow{2}{*}{$\begin{array}{c}\text { Fall- } \\
\text { through }\end{array}$} & \multirow{2}{*}{$\begin{array}{c}\text { Pre- } \\
\text { albumin }\end{array}$} & \multirow[b]{2}{*}{ Albumin } & \multirow{2}{*}{$\begin{array}{c}\text { Post- } \\
\text { albumin }\end{array}$} & \multirow{2}{*}{$\begin{array}{l}\text { 2-Mer- } \\
\text { capto- } \\
\text { ethanol }\end{array}$} & \multirow[b]{2}{*}{ Control } \\
\hline & & $19 \mathrm{~S}$ & Int. & $7 \mathrm{~S}$ & Alb. & & & & & & \\
\hline & 0 to $4+$ & & & & & & & & & & \\
\hline $\mathrm{Em}$ & 3 & 6 & 2 & 4 & $\mathbf{0}$ & 4 & $\begin{array}{l}0 \\
5\end{array}$ & $\begin{array}{l}9 \\
6\end{array}$ & 7 & 6 & 10 \\
\hline Do & 3 & 10 & 5 & 3 & 0 & 5 & 5 & & 10 & 7 & 13 \\
\hline $\mathrm{Sn}$ & 1 & 6 & 3 & 3 & 0 & & & & & 4 & 10 \\
\hline $\mathrm{Db}$ & 0 & 10 & 0 & 0 & 0 & & & & & 0 & 10 \\
\hline Dn & 0 & 8 & 0 & 0 & 0 & 0 & 0 & 0 & 7 & 0 & 9 \\
\hline $\mathrm{Bc}$ & 0 & 8 & 0 & 0 & 0 & & & & & $\mathbf{0}$ & 10 \\
\hline Yd & 0 & 4 & 0 & 0 & 0 & & & & & 0 & 10 \\
\hline $\mathrm{Be}$ & 0 & 5 & 0 & 0 & 0 & $0^{*}$ & & & + & $0 \dagger$ & 10 \\
\hline
\end{tabular}

* Rheumatoid factor activity determined by FII precipitin test and recorded as present $(+)$ or not present $(0)$. $\dagger$ Rheumatoid factor activity determined by latex fixation test performed at $\mathrm{pH}$ 7.0. 
The rheumatoid factor activity of serum $\mathrm{Db}$, which contained no intermediate complexes, was present at the bottom of the gradient where $19 \mathrm{~S}$ gamma globulin was concentrated. Serum Em, on the other hand, with $3+$ intermediate complexes, contained rheumatoid factor activity well into the $7 \mathrm{~S}$ region of the gradient (tubes 9 to 20, approximately) where no $19 \mathrm{~S}$ gamma globulin was detected immunologically. The bimodal distribution of activity with peaks in both $7 \mathrm{~S}$ and $19 \mathrm{~S}$ regions is indicative of the presence of two sizes of molecules with rheumatoid factor activity.

The results of the density gradient experiments are tabulated in Table II. Experiments were repeated on several occasions with identical results. All sera with intermediate complexes (Em, Do, and Sn) contained rheumatoid factor activity in both $7 \mathrm{~S}$ and $19 \mathrm{~S}$ regions of the gradient. In sera with no intermediate complexes, the rheumatoid factor activity was present in the $19 \mathrm{~S}$ regions only.

Column chromatography. The chromatographic experiments are summarized in Table II. Two patterns of distribution of rheumatoid factor activity were noted. In serum Dn (Figure 6), the activity was found in the postalbumin eluate of the chromatograph ( 80 to $140 \mathrm{ml}$ ) where $19 \mathrm{~S}$ gamma globulin was present. In serum Em (Figure 7), however, a bimodal distribution of activity with peak activity in the initial protein eluate (fall-through, 20 to $42 \mathrm{ml}$ ), albumin (86 to $105 \mathrm{ml}$ ), and postalbumin regions is seen. $19 \mathrm{~S}$

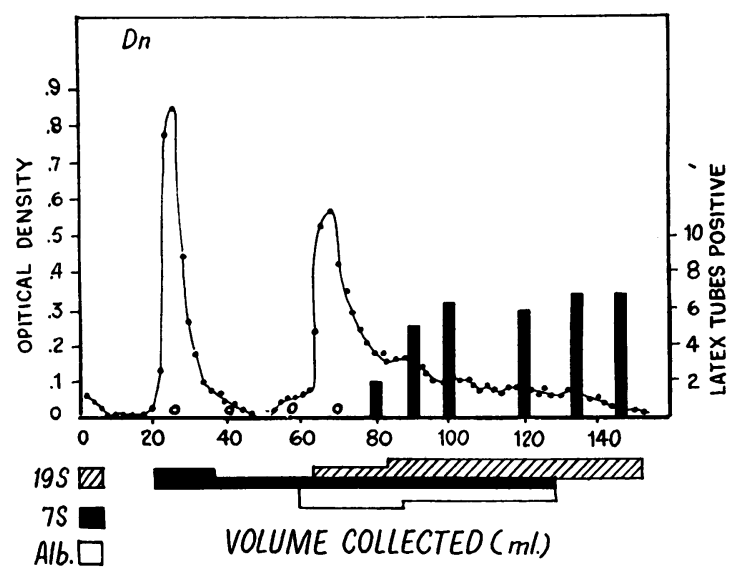

Fig. 6. Chromatographic pattern of Serum DN. Location of immunologically detected 7 and $19 \mathrm{~S}$ gamma globulin and albumin indicated below.

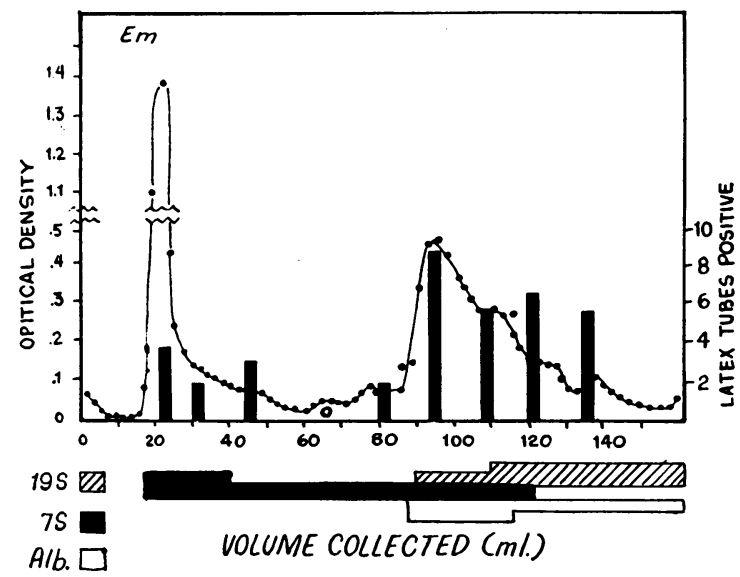

Fig. 7. Chromatographic pattern of Serum Em. Location of immunologically detected 7 and $19 \mathrm{~S}$ gamma globulin and albumin indicated below.

Gamma globulin was not detected in any of the prealbumin fractions.

All active prealbumin fractions contained variable amounts of acid-dissociable intermediate complexes. The fall-through peak of serum Em (20 to $42 \mathrm{ml}$, approximately; Figure 8), contained $67 \% 7 \mathrm{~S}$ and $33 \% 10 \mathrm{~S}$ gamma globulin. The $10 \mathrm{~S}$ complexes dissociated completely into $7 \mathrm{~S}$ gamma globulin in acid buffers $(\mathrm{pH} 3.0)$.

Some variability of the chromatographs obtained from sera Em and Do was noted. The active complexes were eluted in either the fallthrough peak, or prealbumin region, or in both
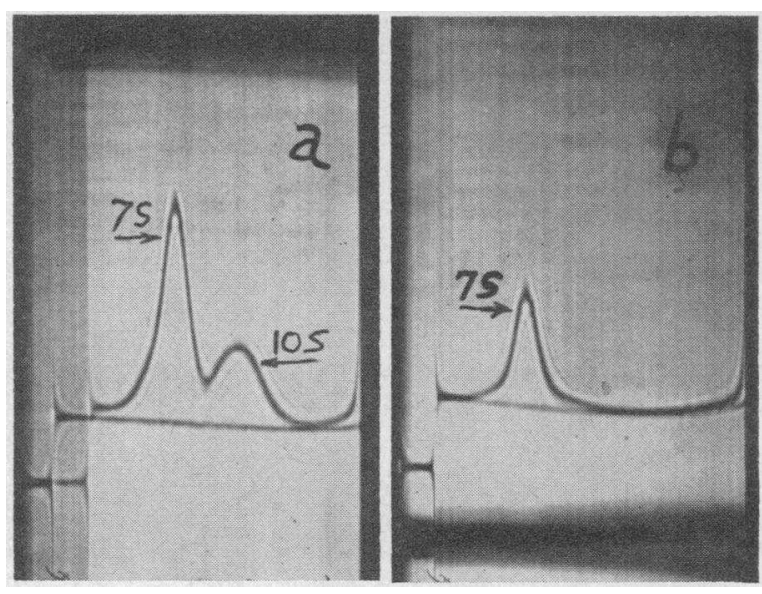

Fig. 8. Ultracentrifuge pattern of the fallTHROUGH PEAK OF EM CHROMATOGRAM. a) Untreated and $b$ ) at lower concentration after dialysis against glycine-saline buffer of $\mathrm{pH}$ 3.0. Centrifugation proceeds from left to right. 
of these fractions. The reason for this variability is not understood.

Effect of 2-mercaptoethanol on rheumatoid factor activity. In sera with no intermediate complexes, rheumatoid factor activity was completely abolished when made $0.1 \mathrm{M}$ with respect to 2-mercaptoethanol. Considerable reactivity remained, however, in sera with intermediate complexes when similarly treated (Table II).

\section{DISCUSSION}

Three interpretations of the interaction of rheumatoid factor with gamma globulin have been proposed: $a$ ) nonspecific, $b$ ) complement-like, and $c$ ) antigen-antibody. It seems unlikely that the interaction is nonspecific in view of the apparent specificity of the rheumatoid factors for human, or animal gamma globulins, or both (18), and the recently demonstrated specificity of the anti-Gm factors for native gamma globulin of different $\mathrm{Gm}$ specificities (9). The affinity of rheumatoid factor for antigen-antibody complexes has suggested a complement-like action (19). The nonidentity of rheumatoid factor with any of the main components of complement, or with conglutinin, or properdin makes this hypothesis unlikely (20), although it does not exclude the possibility that the rheumatoid factor is a complement-like substance of a type not previously described.

Most widely held at the present time is the concept that the rheumatoid factor is an antibody against gamma globulin. This hypothesis is supported by the many similarities between rheumatoid factor and the high-molecular-weight antibodies (7). Both are gamma ${ }_{1}$ globulins with approximately $10 \%$ carbohydrate and a molecular weight of about $1,000,000$. Both are dissociable into $7 \mathrm{~S}$ subunits with sulfhydryl reagents, have antigenic determinants in common, and are synthesized by cells of the lymphocyte-plasma cell series (8).

Although the natural antigen is unknown, the increased reactivity of rheumatoid factor with aggregated gamma globulin suggests that the antigenic stimulus may be gamma globulin in an altered form. Antigen-antibody complexes with biological effects similar to those of aggregated gamma globulin (21) have been suggested as natural antigens (6). This concept is supported by the findings of Milgrom and Dubiski (22) of rheumatoid factor-like substances in rabbits immunized with isologous antigen-antibody complexes. Rheumatoid factor-like substances have also been demonstrated in rabbits immunized with pure ovalbumin (23) and with $E$. coli grown on a synthetic medium (24). The immune complexes (ovalbumin-antiovalbumin, $E$. coli-anti-E. coli) produced in these animals presumably stimulated the production of rheumatoid-like factors. More difficult to understand, however, is the occurrence of anti-Gm factors in some rheumatoid sera that are specific for $\mathrm{Gm}$ types not present in those sera (25).

As a result of uncertainties such as these and the lack of more direct evidence concerning the natural antigen and immunizing events, the antibody nature of the rheumatoid factors can be considered suggestive, but not firmly established at the present time.

The finding of intermediate complexes in some rheumatoid sera by Kunkel and co-workers (10) led to a new approach to this problem. These workers suggested that the intermediate complexes may represent a low-molecular-weight rheumatoid factor, although they were unable to demonstrate any interaction between the isolated complexes and aggregated gamma globulin in the FII precipitin test, or in the $\mathrm{Rh}$ rheumatoid test. However, alterations in the pattern of the complexes produced by adding normal gamma globulin to the serum were reminiscent of antigen-antibody complexes formed in antigen excess.

The report by Meltzer and Franklin (26) of a single serum with acid dissociable intermediate complexes whose rheumatoid factor and cryoglobulin activity resided in the $7 \mathrm{~S}$ portion of the serum is consistent with this hypothesis. Also pertinent are the studies of Osterland, Harboe, and Kunkel (27) which demonstrated the agglutination of red blood cells sensitized with a pepsintreated, incomplete, anti-Rh antibody by a $7 \mathrm{~S}$ component of rheumatoid sera. 19 S Rheumatoid factor agglutinated only red blood cells sensitized with untreated, incomplete, anti-Rh antibody.

In this study, a factor that interacts with human gamma globulin in the latex fixation reaction, but is stable in the presence of sulfhydryl reagents has been demonstrated in sera containing intermediate complexes. Hypergammaglobulinemia per 
se was not related to the presence of low-molecular-weight rheumatoid factor, since these factors could not be demonstrated in serum Yd (elevated $7 \mathrm{~S}$ ) or in serum Be (elevated $19 \mathrm{~S}$ ), although both contained rheumatoid factor in high titer. The factor sediments in the $7 \mathrm{~S}$ and intermediate regions of a density gradient and in prealbumin chromatographic fractions. The intermediate complexes, readily dissociable in moderately acidic media, may consist of normal gamma globulins complexed with other gamma globulins containing the specific rheumatoid-factor combining sites. Low-molecular-weight rheumatoid factor activity, however, was demonstrable only in those chromatographic fractions containing intermediate complexes (10 to $14 \mathrm{~S}$ ), and not in fractions consisting entirely of $7 \mathrm{~S}$ gamma globulin. The possibility exists, therefore, that the complexes and not their acid-dissociable products are the smallest molecules containing the specific rheumatoid-factor combining sites.

It may be postulated that molecules of gamma globulin capable of complexing with other gamma globulins are synthesized in some rheumatoid patients by processes that may or may not be immunologic in nature. Since the complexes are dissociable in moderate acid or alkali, but stable in the presence of sulfhydryl reagents, neither peptide nor disulfide bonds are involved in the complexing process. The interaction, therefore, probably involves electrostatic and possibly other forces, and results in both complex formation and perhaps the creation of the unique secondary and tertiary structure that contains the specific rheumatoidfactor combining sites.

A mechanism such as this is not unreasonable in view of recent findings concerning the relationship of structure to activity of the enzyme ribonuclease. Vithayathil and Richards (28) fractionated ribonuclease by the hydrolysis of a single peptide bond into a twenty-carbon peptide and a residual protein fragment. These products, by themselves inactive, interact and regain full activity when mixed together. In the presence of moderate acidity, however, the complex is dissociated with complete loss of activity, indicating the participation of noncovalent bonds in the determination of a structure appropriate to the formation of an active enzyme.

The stable titer of rheumatoid factor in the sera of most cases of rheumatoid arthritis contrasts with the marked fluctuations in titer noted in sera obtained from several of our patients with intermediate complexes. That these fluctuations are due to changing amounts of $7 \mathrm{~S}$ rheumatoid factor is indicated by the parallel changes in the amounts of intermediate complexes. A rheumatoid factor titer that closely follows the disease activity is seen in a variety of infectious diseases (e.g., tuberculosis and subacute bacterial endocarditis) $(3,29)$. It seems possible, therefore, that changes in the activity of the rheumatoid process in those patients whose sera contained intermediate complexes may be reflected by the titer of rheumatoid factor. The marked decrease in intermediate complexes and latex fixation titer noted in serum Em in January, 1962 occurred after a transurethral prostatectomy and an E. coli septicemia. There was, however, no change in corticosteroid or other specific antirheumatoid therapy. It is possible that the interaction of $E$. coli-anti-E. coli complexes formed in this serum with the rheumatoid factors resulted in their elimination from the serum, and hence the marked decrease in intermediate complexes and rheumatoid factor found in the serum of January, 1962. The variation in rheumatoid factor found in serum $\mathrm{Sn}$, however, was not attended by any change in therapy, or by any apparent change in clinical status. Clearly, a larger series is necessary before any relationship between disease activity and $7 \mathrm{~S}$ rheumatoid factor can be established.

Low-molecular-weight rheumatoid factor has been detected only in those sera containing intermediate complexes. It seems likely, however, that complexes are present in many rheumatoid sera in amounts too small to be demonstrable by analytical ultracentrifugation. In retrospect, small amounts of intermediate complexes have been found in many rheumatoid sera. It is difficult, however, to identify them with certainty with the complexes described here. An analogous situation is known to exist with respect to $19 \mathrm{~S}$ rheumatoid factor, which forms $22 \mathrm{~S}$ complexes in sufficient amount to be demonstrable by analytical ultracentrifugation only in those rheumatoid sera with high titers in the latex fixation reaction (2).

Attempts to isolate $7 \mathrm{~S}$ gamma globulins with rheumatoid factor activity from sera containing 
intermediate complexes are currently in progress. Determination of the specificity or lack of specificity of the low-molecular-weight rheumatoid factors for antigen-antibody complexes, animal gamma globulins, and gamma globulins of different $\mathrm{Gm}$ specificities would also be of considerable interest. Preliminary data suggests that the $7 \mathrm{~S}$ rheumatoid factors are not reactive with rabbit gamma globulin in the sensitized sheep-cell agglutination reaction.

The existence of 7 and $19 \mathrm{~S}$ forms of rheumatoid factor, analogous to the low- and high-molecular-weight forms of many other antibodies, supports the concept of the antibody nature of these factors. It must be emphasized, however, that these findings constitute circumstantial, and not direct, evidence for this theory.

\section{SUM MARY}

The distribution of rheumatoid factor activity in sera with and without acid-dissociable intermediate complexes has been studied by means of density gradient and analytical ultracentrifugation, column chromatography, and disulfide bond reduction experiments.

In sera with intermediate complexes, a bimodal distribution of activity noted in density gradient and chromatographic experiments indicates the presence of a low-molecular-weight rheumatoid factor in addition to the classical $19 \mathrm{~S}$ type. Treatment with 2-mercaptoethanol completely inactivated control rheumatoid and hypergammaglobulinemic sera, but considerable activity remained in similarly treated sera with intermediate complexes. Considerable variability in the amount of intermediate complex and in the titer of rheumatoid factor was demonstrated in several sera drawn at different times.

The possible significance of these findings in terms of the antibody nature of the rheumatoid factors is discussed.

\section{ACKNOWLEDGMENT}

The skilled technical assistance of Miss Dolores Czerwinski is gratefully acknowledged.

\section{REFERENCES}

1. Chodirker, W. B., and T. B. Tomasi, Jr. Low molecular weight rheumatoid factors. Arthr. Rheum. 1962, 5, 641 .
2. Franklin, E. C., H. R. Holman, H. J. Müller-Eberhard, and $H$. G. Kunkel. An unusual protein component of high molecular weight in the serum of certain patients with rheumatoid arthritis. J. exp. Med. 1957, 105, 425.

3. Singer, J. M., C. M. Plotz, F. M. Peralta, and H. C. Lyons. The presence of anti-gamma globulin factors in sera of patients with active pulmonary tuberculosis. Ann. intern. Med. 1962, 56, 545.

4. Kunkel, H. G., H. J. Simon, and H. Fudenberg. Observations concerning positive serologic reactions for rheumatoid factor in certain patients with sarcoidosis and other hyperglobulinemic sera. Arthr. Rheum. 1958, 1, 289.

5. Peltier, A., and C. L. Christian. Presence of rheumatoid factor in sera from patients with syphilis. Arthr. Rheum. 1959, $2,1$.

6. Christian, C. L. The possible significance of the "rheumatoid factor." Arthr. Rheum. 1961, 4, 86.

7. Kunkel, H. G. The rheumatoid factors. Arch. intern. Med. 1959, 104, 832.

8. Mellors, R. C., A. Nowoslawski, L. Korngold, and B. L. Sengson. Rheumatoid factor and the pathogenesis of rheumatoid arthritis. J. exp. Med. 1961, $113,475$.

9. Harboe, M. Simultaneous occurrence of hemagglutinating substances of different specificities in rheumatoid sera. Acta path. microbiol. scand. 1960, 49, 381.

10. Kunkel, H. G., H. J. Müller-Eberhard, H. H. Fudenberg, and T. B. Tomasi. Gamma globulin complexes in rheumatoid arthritis and certain other conditions. J. clin. Invest. 1961, 40, 117.

11. Tomasi, T. B., Jr., H. H. Fudenberg, and N. Finby. Possible relationship of rheumatoid factors and pulmonary disease. Amer. J. Med. 1962, 33, 243.

12. Kritzman, J., H. G. Kunkel, J. McCarthy, and R. C. Mellors. Studies of a Waldenström-type macroglobulin with rheumatoid factor properties. J. Lab. clin. Med. 1961, 57, 905.

13. Kabat, G. A., and M. M. Mayer. Experimental immunochemistry. Springfield, Ill., Charles C Thomas, 1961, p. 556.

14. Kunkel, H. G. Macroglobulins and high molecular weight antibodies in The Plasma Proteins, F. W. Putnam, Ed. New York, Academic Press, 1960, p. 279.

15. Fahey, J. L. Chromatography of serum proteins in normal and pathological sera: the distribution of protein-bound carbohydrate and cholesterol, siderophilin, thyroxine-binding protein, $\mathrm{B}_{12}$-binding protein, alkaline and acid phosphatases, radio-iodinated albumin and myeloma proteins. J. clin. Invest. 1958, 37, 272.

16. Singer, J. M., and C. M. Plotz. The latex fixation test. I. Application to the serologic diagnosis of rheumatoid arthritis. Amer. J. Med. 1956, 21, 888.

17. Ouchterlony, O. Antigen-antibody reactions in gels. IV. Types of reactions in coordinated systems of 
diffusion. Acta path. microbiol. scand. 1953, 32, 24. Abruzzo, J. L., and C. L. Christian. The induction 231.

18. Vaughan, J. H., P. J. Ellis, and H. Marshall. Quantitative considerations of the rheumatoid factor. J. Immunol. 1958, 81, 261.

19. Vaughan, J. H. Serum responses in rheumatoid arthritis. Amer. J. Med. 1959, 26, 596.

20. Laurell, A-B., and R. Grubb. Complement, complement components, properdin and agglutination promoting factors in rheumatoid arthritis. Acta path. microbiol. scand. 1958, 43, 310.

21. Ishizaka, T., and $\mathrm{K}$. Ishizaka. Biological activities of aggregated gamma globulin. I. Skin reactive and complement-fixing properties of heat denatured gamma globulin. Proc. Soc. exp. Biol. (N. Y.) 1959, 101, 845.

22. Milgrom, F., and S. Dubiski. Antigenicity of antibodies of the same species. Nature (Lond.) 1957, $179,1351$.

23. Aho, K., and O. Wager. Production of "anti-antibodies" in rabbits. Ann. Med. exp. Fenn. 1961, 39, 79. of a rheumatoid factor-like substances in rabbits. J. exp. Med. 1961, 114, 791.

25. Steinberg, A. G., B. D. Giles, and R. A. Stauffer. Gm-like factor present in Negroes and rare or absent in whites: its relation to $\mathrm{Gm}^{2}$ and $\mathrm{Gm}^{x}$. Amer. J. hum. Genet. 1960, 12, 44.

26. Meltzer, M., and E. C. Franklin. Interaction of $\gamma$-globulins. A study of cryoglobulins with and without rheumatoid factor activity (abstract). Arthr. Rheum. 1962, 5, 117.

27. Osterland, C. K., M. Harboe, and H. G. Kunkel. Rheumatoid factors (7S and 19S types) reacting with different portions of the $\gamma$-globulin molecule. Arthr. Rheum. 1962, 5, 312.

28. Vithayathil, P. J., and F. M. Richards. The carboxyl and amide groups of the peptide component of ribonuclease-S. J. biol. Chem. 1961, 236, 1380.

29. Williams, R. C., Jr., and H. G. Kunkel. Rheumatoid factor, complement, and conglutinin aberrations in patients with subacute bacterial endocarditis. J. clin. Invest. 1962, 41, 666. 